\title{
Domestication Syndrome in Caimito (Chrysophyllum cainito L.): Fruit and Seed Characteristics ${ }^{1}$
}

\author{
Ingrid M. Parker ${ }^{*, 2}$, Isis López ${ }^{3}$, Jennifer J. Petersen ${ }^{4}$, Natalia Anaya ${ }^{5}$, \\ Luis Cubilla-Rios ${ }^{5}$, and Daniel Potter ${ }^{4}$
}

${ }^{2}$ Department of Ecology and Evolutionary Biology, University of California, Santa Cruz, Santa Cruz, CA, USA

${ }^{3}$ Smithsonian Tropical Research Institute, Gamboa, Panamá, República de Panamá

${ }^{4}$ Department of Plant Sciences, University of California, Davis, Davis, CA, USA

${ }^{5}$ Laboratorio de Bioorganica Tropical, Universidad de Panamá, Panamá, República de Panamá

*Corresponding author; e-mail: parker@biology.ucsc.edu

\begin{abstract}
Domestication Syndrome in Caimito (Chrysophyllum cainito L.): Fruit and Seed Characteristics: The process of domestication is understudied and poorly known for many tropical fruit tree crops. The star apple or caimito tree (Chrysophyllum cainito L., Sapotaceae) is cultivated throughout the New World tropics for its edible fruits. We studied this species in central Panama, where it grows wild in tropical moist forests and is also commonly cultivated in backyard gardens. Using fruits collected over two harvest seasons, we tested the hypothesis that cultivated individuals of $C$. cainito show distinctive fruit and seed characteristics associated with domestication relative to wild types. We found that cultivated fruits were significantly and substantially larger and allocated more to pulp and less to exocarp than wild fruits. The pulp of cultivated fruits was less acidic; also, the pulp had lower concentrations of phenolics and higher concentrations of sugar. The seeds were larger and more numerous and were less defended with phenolics in cultivated than in wild fruits. Discriminant Analysis showed that, among the many significant differences, fruit size and sugar concentration drove the great majority of the variance distinguishing wild from cultivated classes. Variance of pulp phenolics among individuals was significantly higher among wild trees than among cultivated trees, while variance of fruit mass and seed number was significantly higher among cultivated trees. Most traits showed strong correlations between years. Overall, we found a clear signature of a domestication syndrome in the fruits of cultivated caimito in Panama.
\end{abstract}

Síndrome de domesticación en caimito (Chrysophyllum cainito L): Características de las frutas y semillas: El proceso de domesticación de muchos árboles frutales tropicales es poco estudiado y entendido. El caimito (Chrysophyllum cainito L., Sapotaceae) es cultivado, por su fruto comestible, en todas las regiones tropicales de América. Hemos estudiado esta especie en Panamá central, donde crece en huertos caseros y en poblaciones silvestres del bosque húmedo tropical. Usando frutos colectados en dos años de cosecha, probamos la hipótesis de que las semillas y los frutos de individuos cultivados e individuos silvestres de C. cainito tienen características distintas debido a la domesticación. Encontramos que los frutos de los individuos cultivados fueron significativa y sustancialmente más grandes, con mayor cantidad de pulpa y menos exocarpo que los frutos de individuos silvestres. La pulpa de la fruta de los individuos cultivados fue menos ácida, con menor concentración de compuestos fenólicos y alta concentración de azúcares. Las semillas fueron más grandes, numerosas y con menor autodefensas (compuestos fenólicos) en los individuos cultivados que en los silvestres. El análisis discriminante mostró, entre muchas diferencias significativas, que el tamaño de la fruta y la concentración de azucares fueron los factores más importantes para discriminir entre individuos cultivados y silvestres. La varianza entre individuos fue significativamente mayor dentro de los árboles silvestres que dentro de los árboles cultivados, para los comp-

\footnotetext{
${ }^{1}$ Received 4 September 2009; accepted 4 May 2010; published online 21 May 2010.
} 
uestos fenólicos de la pulpa. En contraste, la varianza fue significativamente mayor entre árboles cultivados para el peso de la fruta y número de semillas. La mayoría de las características demostraron una fuerte correlación entre años. En general, encontramos un patrón claro para el síndrome de la domesticación en la fruta de caimito en Panamá.

Key Words: Domestication, Caimito, Star apple, Fruit size, Chemistry, Phenolics, Trait correlations, Discriminant analysis.

\section{Introduction}

The evolutionary and genetic aspects of the process of domestication have been studied intensively in temperate cereal crops and pulses and are fairly well understood for those crops (reviewed in Doebley et al. 2006; Fuller 2007; Harlan et al. 1973; Purugganan and Fuller 2009). In contrast, we have a much less comprehensive knowledge of domestication in perennial crops such as tree fruits and nuts (Doebley et al. 2006), even though these species make up an important component of human nutrition throughout the world (Haq et al. 2008; Schreckenberg et al. 2006; Simpson and Ogorzaly 2001). It has been suggested that the study of tree crops may reveal fundamental differences in the process of domestication and its genetic consequences (Gepts 2004; Wiersum 1997). The fact that tree crops have long lifespans and that they are often asexually propagated limits the number of generations that have passed since their first cultivation by humans and the degree of evolution that has occurred under human selection in these taxa (Clement 1989; Zohary and Spiegel-Roy 1975).

Clement (1999) described five stages in the domestication process: 1) wild (plants exhibit no modification due to human activity), 2) incidentally co-evolved (plants show adaptations to anthropogenically disturbed environments but have not been modified by human selection), 3) incipiently domesticated (plants show some modification due to human selection, but the average phenotype is still within the range found in the wild), 4) semi-domesticated (plants show significant modification by human selection but are not dependent on human intervention for survival), and 5) domesticated (plants can only survive in cultivated landscapes). In species that are still in the early stages of domestication (Clement's stages 2-4), cultivated and wild-type individuals will coexist in close proximity in the region of origin, where we can study how traits have responded to anthropogenic selection in the face of continued gene flow between wild and improved types. Some of our best-known examples of plants in the early stages of domestication come from Mesoamerica, where native crop species are frequently cultivated in traditional agroecosystems such as home gardens (e.g., Blancas et al. 2009; Bost 2009; Hughes et al. 2007; Miller and Schaal 2005).

We expect fruit and seed characteristics of tree crops to change in predictable ways under anthropogenic selection during the domestication process, leading to a type of domestication syndrome for edible fruits (Baker 1972; De Candolle 1885; Rindos 1984; Zohary 2004; Zohary and Spiegel-Roy 1975). Compared to their wild relatives, edible fruits of domesticated taxa tend to be larger and sweeter or higher in oil content (Maranz and Wiesman 2003; Zohary and Spiegel-Roy 1975). The ratio of edible product to waste, or "economic ratio" (Clement 1989), goes up. We also expect to see a reduction in toxic compounds that confer defense against natural enemies at the cost of palatability (Baker 1972; Jackson 1991; Johns 1990).

In addition to changing mean trait values, anthropogenic selection could have contradictory effects on the variance of traits. Due to selection bottlenecks, we expect neutral variation to decline with cultivation in domesticated species (Doebley et al. 2006). For particular genes under strong directional selection, the reduction in genetic variation may be even more dramatic (Wright et al. 2005). However, if distinct cultivated varieties are selected for contrasting phenotypes, then phenotypic variance will be higher in cultivated plants (Gepts 2004; Rindos 1984). Some even have used changes in the variance and shape of the distribution of traits as an indicator of the degree of domestication shown by populations of indigenous fruit trees (e.g., Leakey et al. 2004; Leakey et al. 2005a,b).

Chrysophyllum cainito L. (Sapotaceae), commonly known as caimito or star apple, is highly desired throughout the tropics for its value as an 
ornamental tree and its production of large, edible fruits. Caimito is presently cultivated throughout the Caribbean, Central America, and parts of South America as well as in Southeast Asia (Morton 1987). Various hypotheses have been suggested for its geographic and taxonomic origin, as well as its center of domestication (Pennington 1990; Standley and Williams 1967). Historical accounts made by plant explorers in the 16th and 17 th centuries mention $C$. cainito as occurring in the islands of the Lesser and Greater Antilles as well as on the mainland and islands of the Bay of Panama (Oviedo y Valdés 1525, cited in Patiño 2002; Sloane 1725). Patrick Brown mentions C. cainito as being cultivated all over the island of Jamaica and that it "thrives (there) with very little care" (Browne 1756). Seemann (1852) reports the presence of both wild and cultivated caimito in the Isthmus of Panama. Our preliminary molecular genetic results (Petersen et al. 2008) show much greater overall diversity of the species in Panama compared to northern Central America, Mexico, and the Caribbean, and support the hypothesis that C. cainito was domesticated in Panama.

In contemporary Panama, C. cainito is widely distributed as a natural part of tropical lowland forest. In fact, this species is promoted as a native tree for environmentally sensitive reforestation efforts, for example, by the Proyecto de Reforestación con Especies Nativas (PRORENA [http://prorena.research.yale.edu], access date 29 April 2010). The forest plot network that bisects the Panamanian Isthmus documents the presence of $C$. cainito at many sites on the Pacific side of central Panama (Perez and Condit, Tree Atlas of Panama, https://ctfs.arnarb.harvard.edu/webatlas/ maintreeatlas.php, access date 29 April 2010). In the wild, C. cainito is found at low density, does not produce fruit until the tree reaches the canopy of the forest, maintains few branches below $10 \mathrm{~m}$, and produces ripe fruits over only a short time interval; taken together, these aspects complicate the study of this species in wild populations.

Cultivated caimito is a common component of Panamanian home gardens and small ranchos. Usually only one or two individuals are planted per property, as fruits are not sold on a commercial scale. While an owner will occasionally report that a tree "arrived on its own," presumably dispersed by a bird or mammal, usually trees in gardens have been planted from seeds selected from a fruit, usually a fruit provided by a friend or neighbor (I. Parker and J. Petersen, personal observation). Sometimes plants have been purchased as seedlings from a nursery. During the Canal Zone era (1913-1977), C. cainito was planted horticulturally as a street tree in some communities within and surrounding Panama City. Thus the cultivation of $C$. cainito trees in Panama has included a combination of individual selection via fruits and seeds, with some relatively small-scale central production and distribution of plants. In addition, human migration between the Antilles and Panama may have resulted in the importation of caimito seeds from the Antilles.

Our goal was to test the hypothesis that cultivated individuals of $C$. cainito show signs of a domestication syndrome: Distinctive fruit and seed characteristics that are typically associated with domestication relative to wild phenotypes growing in the same region. As a putative region of domestication for this species and an area with extensive populations in protected forests, Panama is the ideal place for such a study. We compared fresh collections from wild and cultivated trees in central Panama for a range of morphological and fruit quality traits to infer how human selection has influenced these traits. We then used Discriminant Analysis to investigate the relative importance of various traits for distinguishing cultivated fruits from wild fruits. In this paper, we also present information on the variance in traits, correlations among traits, and variation in trait values from year to year.

\section{Methods}

\section{Study Site And Collections}

We chose to focus our collections in central Panama, where caimito is cultivated in both rural and urban communities set within the context of wild populations in protected forests. Central Panama includes extensive areas of semi-deciduous, tropical forest, primarily associated with the Panama Canal watershed. The zone around the Canal includes more than 850 species of native trees and shrubs (Pyke et al. 2001). There is a natural rainfall gradient of 1,750-3,000 $\mathrm{mm}$ per year from the Pacific to the Caribbean side of the isthmus, with a pronounced dry season (Panama Canal Authority: Republic of Panama 2008). Wild individuals of Chrysophyllum cainito are distributed at low density throughout the forests 
of the Canal Zone, particularly on the Pacific side of the continental divide, where they are found in old-growth as well as second-growth forests (Condit et al. 2002).

For the purpose of our sample, we defined trees as wild if they were in natural (although not necessarily primary) forest habitat and if, to the best of our knowledge, people did not plant them. We used surveys and the knowledge of local indigenous people to locate over 150 adult wild trees, but only a percentage of these produced fruit in any given year. We included in our study every wild tree from which we could obtain enough fruits, including trees from Parque Nacional Soberanía, Old Gamboa Road, Venta de Cruces, Parque Nacional Camino de Cruces, and Parque Natural Metropolitano (Fig. 1). Sample sizes differ among variables and years and are provided below; our sample sizes increased from 2006 to 2008 as we found new individuals and added new sites.

We defined trees as cultivated if they were obviously planted either alongside rural dwellings or as horticultural plantings in more urbanized areas. Whenever possible, we interviewed owners to obtain direct information about who planted the tree; we did not use trees whose origin was ambiguous. Chrysophyllum cainito is primarily propagated by seed, apparently exclusively so in Panama. We roughly matched the sample sizes (details below) and locations of our cultivated sample to the wild tree sample, including trees from the communities of Gamboa, Chilibre, Chilibrillo, Paraíso, Ciudad del Saber, Los Rios, Burunga, and Balboa (Fig. 1). From among the available trees, we chose our cultivated sample based primarily on access, as it was not always possible to get permission from owners to collect fruits.

\section{Fruit and Seed Measurements}

From January 15 to February 27 (2007) and January 10 to March 14 (2008), we collected fruits from wild trees within forested landscapes ( $N=15$ and 29 in 2007 and 2008, respectively), as well as from cultivated trees in gardens and urban plantings ( $N=24$ and 37$)$, across a $30 \mathrm{~km} \times$ $20 \mathrm{~km}$ area in central Panama. Mature, ripe fruits were collected directly from the tree when possible, or freshly fallen fruits were gathered; for some wild trees we set out nylon traps at night and collected fallen fruits in the early morning.
We collected five to thirty fruits per tree, and of these, five (in 2007) or three (in 2008) were randomly selected for analysis. We completed measurements on fruits almost always within several hours of collection, and always within three days. For each fruit, we took a photograph, noted color, measured fresh weight, length and diameter, and toughness using a penetrometer (mean of two measures). We then cut the fruit open and measured the thickness of the exocarp, or rind (mean of two measures). We extracted fluid from the fruit pulp by passing it through a fine filter and assessed sugar content $\left({ }^{\circ} \mathrm{Brix}\right)$ with a hand-held refractometer (mean of two measures). We counted the number of seeds and measured mean seed mass (total mass/number of healthy mature seeds). One wild tree produced no healthy mature seeds, decreasing the sample size for seed mass (and also therefore the multivariate analysis, described below) to 28. Fruit shape is expressed as diameter/length, and proportion allocation to exocarp as (exocarp width x 2)/diameter.

\section{Chemistry of Fruits, Seeds, and Leaves}

In 2006, we measured the chemical characteristics of fruit pulp, seeds, and leaves of wild and cultivated $C$. cainito trees. We collected mature fruits from 11 cultivated and 7 wild $C$. cainito trees from January 27 to February 21 (2006) and sub-sampled randomly as above. For two fruits per tree, the pulp was separated from the exocarp and seeds, homogenized, and frozen immediately. Material was preserved at $-15^{\circ} \mathrm{C}$ for one month followed by storage at $-80^{\circ} \mathrm{C}$ until further processing. We quantified $\mathrm{pH}$ using a digital $\mathrm{pH}$ meter. We then extracted $0.1 \mathrm{~g}$ of material in $1 \mathrm{~mL} \mathrm{MeOH}$ following Azuma et al. (1999). We determined total phenolics in $10 \mu \mathrm{L}$ of extract from absorbance at $725 \mathrm{~nm}$ according to FolinCiocalteu's procedure (Singleton and Rossi 1965). We measured absorbance twice for each sample using a Spectronic 20 spectrophotometer (Thermo Scientific) and express levels of phenolics as Gallic Acid Equivalent (GAE).

We measured the concentration of phenolics in the seeds of eight of the cultivated and five of the wild trees for which we were able to collect enough seed material. Seeds were removed from ripe fruits and stored under ambient temperature and humidity for approximately two months. (A separate study did not reveal any gross-scale difference between fresh and stored seeds, $P=0.63$, 


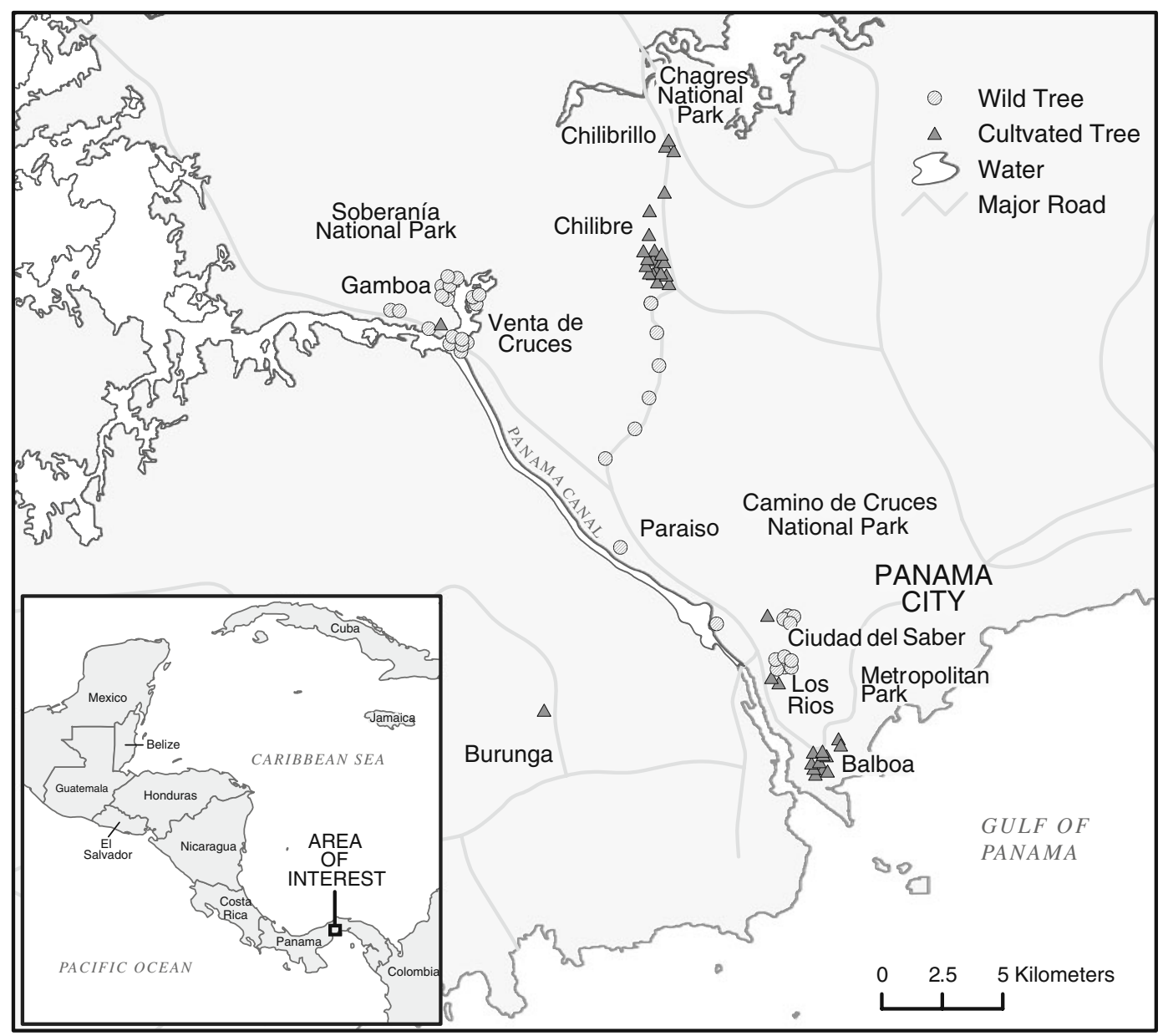

Fig. 1. Locations of sampled wild and cultivated trees of Chrysophyllum cainito in central Panama. Rural communities and urban plantings are interspersed with protected forests harboring populations of wild $C$. cainito.

although the sample size was small $[N=14]$.) We ground seeds with mortar and pestle and extracted $0.1 \mathrm{~g}$ of seed material with $\mathrm{MeOH}$. We quantified levels of total phenolics as above. Because seeds contained lower levels of phenolics, for the Folin-Ciocalteu assay we used $30 \mu \mathrm{L}$ of extract for the dried seeds and extrapolated the values for phenolic levels for $10 \mu \mathrm{L}$ of fresh seed extract.

On May 31, 2006, we collected leaves from shaded branches of 18 cultivated trees and from the lowest branches (often 20 to $25 \mathrm{~m}$ high) of 11 wild trees. From each tree, we collected two mature leaves and a sample of new leaves that were $<60 \%$ fully expanded for comparison (excluding the petiole in both cases). We stored leaves at $-15^{\circ} \mathrm{C}$ for approximately $12 \mathrm{~h}$ until extraction. Levels of phenolics in mature leaves and in developing leaves were determined as above.

\section{Statistical Analysis}

To compare wild and cultivated classes, we used nested ANOVA with trees nested within class (wild, cultivated), and samples (fruits, fruit pulp subsamples, replicate measures) nested within tree. Nested ANOVA also allowed us to test for significant variation among parent trees within the classes. We used Levene's test (Levene 1960) to test for a difference between cultivated and wild trees in the variance (across tree means) of each trait. For any trait that showed heterogeneity of variance, P-values from the ANOVA 
were suspect. Therefore, for the subset of traits that tested significant for Levene's test, we performed Welch's t-test assuming unequal variances on the comparison between wild and cultivated fruits-but this test could not be used to test for significant variance among trees within classes. Chemistry data from 2006 were analyzed separately from the 2008 data. While the geographical logistics of this system did not allow for the sampling of truly independent but comparable regions, our sample in 2008 was large enough to support separating the data into Northern and Southern sub-regions. When the analyses were done separately on these sub-regions, we obtained essentially the same patterns of difference between wild and cultivated classes for the various traits. Therefore, only the combined data are presented here.

Pairwise correlation coefficients were calculated among traits in the 2008 sample (fruit mass, length, diameter, shape, exocarp width, exocarp proportion, toughness, seed number, seed mass, and sugar concentration) and among chemical traits in the 2006 sample (phenolics, pH, and sugar concentration in fruit pulp, and phenolics in seeds). Correlations between fruit and leaf phenolics could not be estimated because they came from different sets of trees.

We used Discriminant Analysis to test whether the classes of wild $(N=28)$ and cultivated $(N=37)$ trees could be distinguished from each other, and what traits contribute to this discrimination. From the 2008 dataset, we included the following variables: Fruit mass, fruit diameter/length, exocarp proportion, toughness, seed number, seed mass, and sugar concentration ( $\left.{ }^{\circ} \mathrm{Brix}\right)$. We left out the most redundant variables: Fruit length, diameter, and absolute exocarp width. We used forward stepwise variable selection to choose variables that significantly contributed to the model $(P<0.05)$, then ran the model.

For all trees in the sample that produced fruits both in 2007 and in 2008 ( $N=28)$, we calculated correlation coefficients between the mean trait value in 2007 and the mean trait value in 2008.

\section{Results \\ Differences between Wild and Cultivated C. CAINITO}

Cultivated fruits were dramatically larger than wild fruits, with an average fresh mass over three times greater (Fig. 2a, Table 1). The variance in fruit mass was significantly higher in the cultivated sample than in the wild sample (Table 1). The comparison of wild vs. cultivated classes assuming unequal variances was still highly significant $(t=7.6, \mathrm{DF}=39.7, P<0.0001)$.

The shape of fruits was slightly wider than long, and shape did not differ significantly between wild and cultivated fruits (Fig. 2b, Table 1). The variance in this shape parameter also did not differ between wild and cultivated fruits (Table 1). Relative allocation to pulp and exocarp changed in the cultivated sample, with exocarp declining significantly from about $11 \%$ of the diameter in wild fruits to $6 \%$ of the diameter in cultivated fruits (Fig. 2c, Table 1). In absolute terms, the width of the exocarp was also significantly greater in wild than in cultivated fruits (Fig. 2d), although we were unable to detect a consistent difference in the toughness of the exocarp using a penetrometer (Table 1). The variance did not differ between wild and cultivated classes for any of the exocarp measures (Table 1).

Cultivated fruits had $40 \%$ more seeds than wild fruits (Fig. 2e, Table 1). In addition, seeds were substantially larger in cultivated fruits, with $50 \%$ greater average mass than in wild fruits (Fig. 2f, Table 1). The cultivated fruit sample also had significantly higher variance in seed number and marginally significantly higher variance in seed mass than the wild sample (Table 1). The comparison of wild vs. cultivated classes assuming unequal variances was still highly significant for both seed number $(t=4.42, \mathrm{DF}=62.6, \quad P<$ $0.0001)$ and seed mass $(t=5.76, \mathrm{DF}=62.9, P<$ 0.0001).

The sugar concentration of the fresh pulp as measured by ${ }^{\circ}$ Brix was substantially $(22 \%)$ and significantly higher in cultivated fruits than in wild fruits (Fig. 3, Table 1). Cultivated fruits were also statistically significantly less acidic, although this difference was rather small (Fig. 3, Table 1). In addition, cultivated fruits had lower concentrations of total phenolics in both the pulp and the seeds (Fig. 3, Table 1). Of all the chemistry traits, only the phenolics in the pulp showed significantly different variance between wild and cultivated, with wild fruits showing much higher variance than cultivated fruits (Table 1). The comparison of wild vs. cultivated classes assuming unequal variances was marginally significant $(t=1.94, \mathrm{DF}=6.91, P=0.093)$. 
a



C

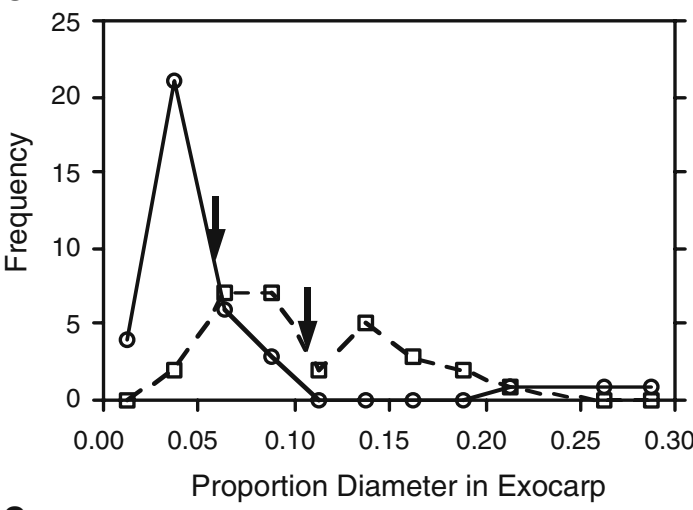

e

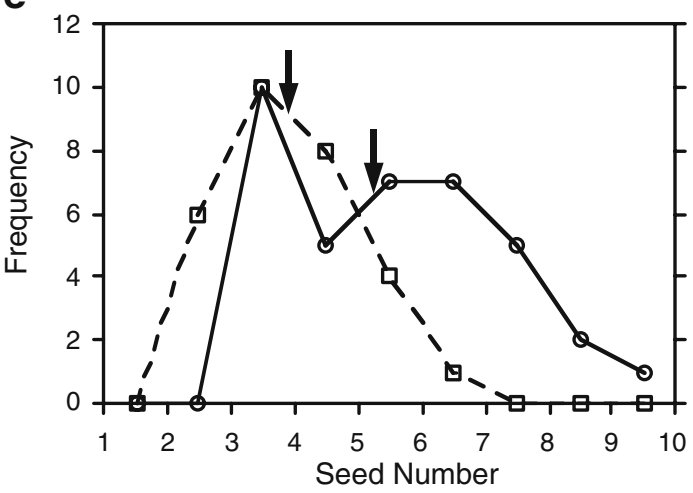

b

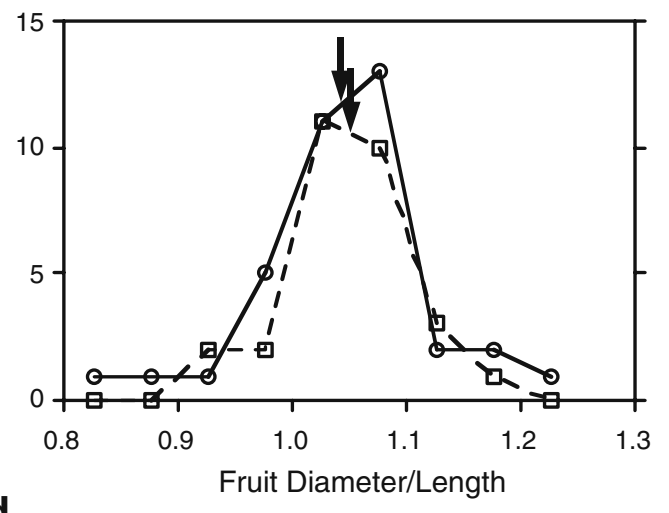

d

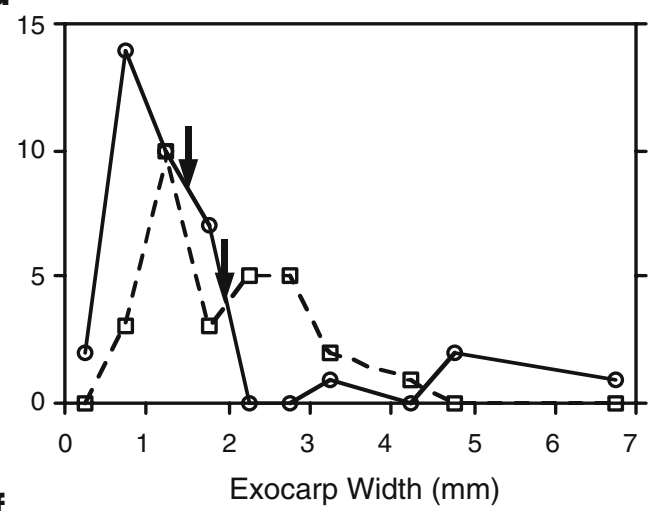

f

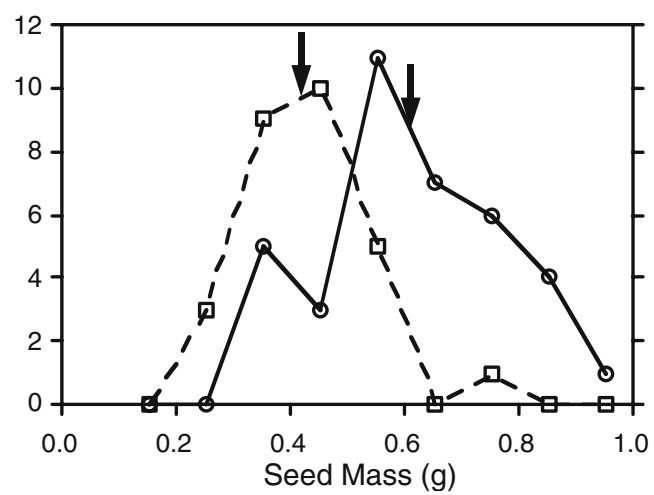

Fig. 2. Frequency distributions of morphometric fruit and seed characteristics of wild trees (squares, dashed lines) and cultivated trees (circles, solid lines) of Chrysophyllum cainito in central Panama. Data are tree means (based on three fruits per tree). Arrows point to the mean values for wild and cultivated classes. a Fresh fruit mass, b Fruit shape (diameter / length), c Proportion of fruit diameter allocated to exocarp, d Absolute width of the exocarp, e Seed number, and f) Seed mass.

There was substantial individual variation for fruit and seed traits. Irrespective of the comparison between the wild and cultivated classes, we found highly significant variation among individual trees nested within classes for every variable (Table 1), even those with a small sample size and those showing no significant differences between wild and cultivated trees. The high statistical power to 

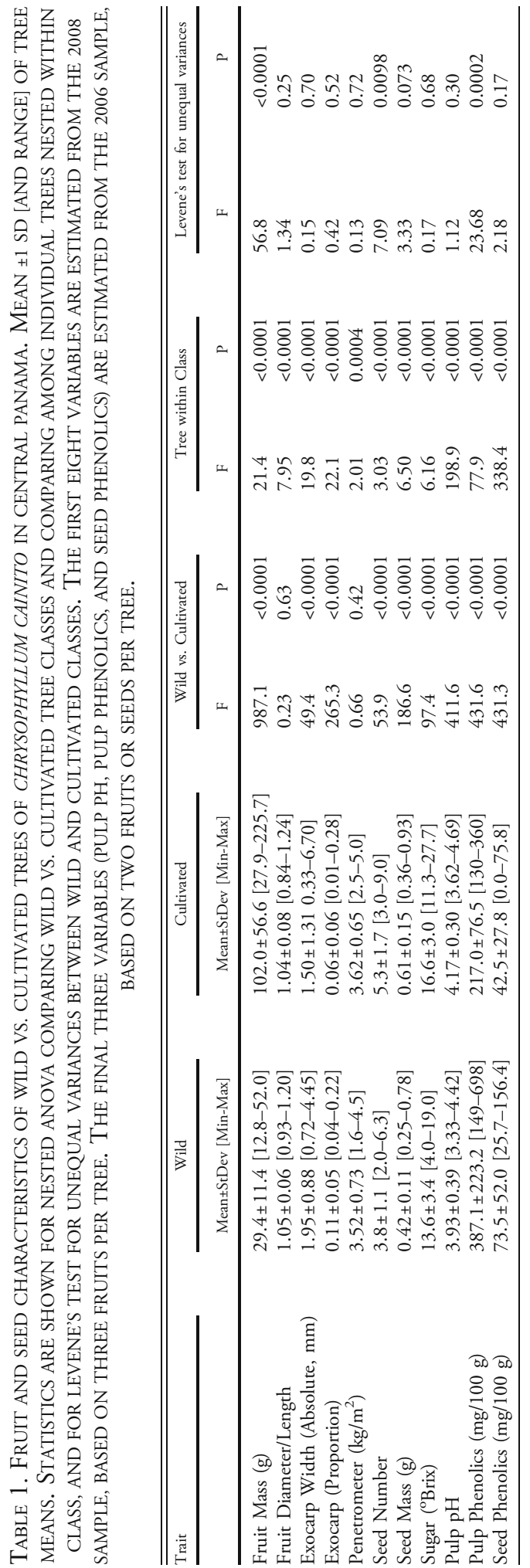

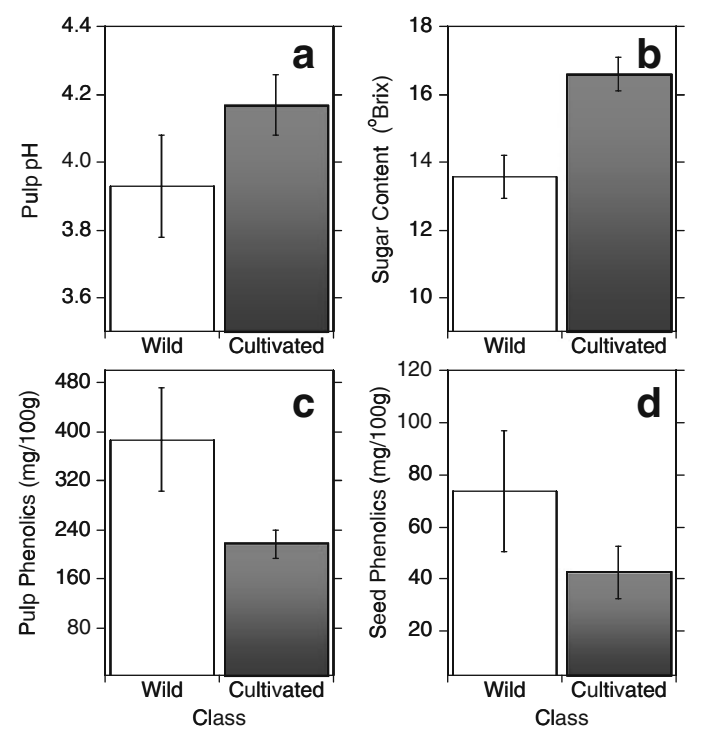

Fig. 3. Chemical traits of fruits and seeds from wild trees (open bars) vs. cultivated trees (shaded bars) of Chrysophyllum cainito in central Panama. Mean $( \pm 1$ SEM) of tree means, based on two ( $\mathrm{pH}$, phenolics) or three ( ${ }^{\circ}$ Brix) fruits per tree, from fruits collected in 2008 ( ${ }^{\circ}$ Brix) or 2006 ( $\mathrm{pH}$, fruit and seed phenolics). a $\mathrm{pH}$ of the fruit pulp, $\mathbf{b}$ Sugar concentration of the fruit pulp ( ${ }^{\circ}$ Brix), c Concentration of total phenolics in the pulp, and $\mathbf{d}$ Concentration of total phenolics in the seeds. Phenolics expressed as mg/100 g Gallic Acid Equivalent (GAE).

detect differences among trees also reflects that there was little variance among the fruits on a given tree.

For all three variables that showed significantly different variance between wild and cultivated samples (fruit mass, seed number, and pulp phenolics), the variance was higher in the class with the higher mean value. Therefore the pattern may be explained simply by the scaling of the variance to the mean. To evaluate this, we also performed Levene's test on the log-transformed values (Table 1). Although with log-transformed data, there was no significant difference for seed number $\left(F_{1,64}=0.56, P=0.46\right)$, cultivated fruits still showed significantly higher variance for fruit mass $\left(\mathrm{F}_{1,64}=7.43, P=0.008\right)$ and lower variance for phenolics $\left(\mathrm{F}_{1,16}=7.43, P=0.018\right)$.

Unlike fruits, mature leaves showed a higher concentration of phenolics (mean \pm SD mg/100 g GAE) in cultivated trees $(898 \pm 178)$ than in wild trees $\left(799 \pm 194, F_{1,27}=5.48, P=0.027\right)$. However, levels of phenolics in young expanding leaves were not different between the two classes of trees (cultivated $=1220 \pm 270$, wild $=1260 \pm 158$, $\mathrm{F}_{1,22}=0.13, P=0.72$ ). Expanding leaves had significantly more phenolics than mature leaves (paired $t=6.14, \mathrm{DF}=23, P<0.0001$ ); the concentration of phenolics in expanding leaves did not significantly predict phenolics in mature leaves $\left(\mathrm{R}^{2}=0.05, N=24, P=0.28\right)$.

\section{Correlations among Traits}

Not surprisingly, the three measures of fruit size (mass, length, and diameter) were all highly correlated with each other $(r=0.96$, Table 2). However, the absolute width of the exocarp was not positively correlated with overall fruit size; rather, as a proportion of the total, it was negatively correlated with fruit size metrics $(r=-0.42)$. In terms of shape, fruits that were longer tended also to be narrower $(r=-0.40$ between length and the shape parameter diameter/length). We found strong positive correlations between fruit size metrics and both seed number $(r=0.53)$ and seed mass $(r=0.76)$.

We found no significant correlations among the different chemical traits, although the sample sizes were small and require a conservative interpretation of these data (Table 3). Of particular interest, the concentration of total phenolics was not significantly correlated between seeds and fruits from the same tree. Phenolics, sugars, and $\mathrm{pH}$ of the pulp were also uncorrelated.

\section{Multivariate Analysis}

MANOVA significantly distinguished wild from cultivated fruits based on the full suite of variables from the 2008 dataset (not including information on phenolics or $\mathrm{pH}$ ) $\left(\mathrm{F}_{7,57}=12.7, P<0.0001\right)$. The forward stepwise variable selection for the discriminant model selected the following variables: Fruit mass $(F=$ 48.7, $P<0.0000001)$, sugars $(F=14.9, P<$ $0.00027)$, and fruit diameter/length $(F=4.2$, $P=0.044)$. The discriminant function resulted in only seven misclassified trees (one wild misclassified as cultivated, and six cultivated misclassified as wild) and -2 Log Likelihood= 17.6. Plotting sugar concentration ( ${ }^{\circ}$ Brix ) against fruit mass reveals how well these two variables alone distinguish wild from cultivated trees (Fig. 4). 


\section{YEAR-TO-YeAR VARIABILITY}

Only 28 trees produced enough fruits in both 2007 and 2008 to be included in the harvest both years. Statistically, all traits were significantly correlated between the years (Table 4). Fruit size measures (mass, length, diameter) were very highly correlated across years $(r=0.87-0.90)$. Fruit shape, seed number, seed mass, toughness, and allocation to exocarp were moderately strongly correlated across the years $(r=0.42-0.77)$. Of all the traits, sugar concentration was least well correlated across years $(r=0.40)$. For comparison, two fruits picked at random from the same tree in $2008(N=66)$ had a correlation coefficient of 0.94 for fruit mass and 0.68 for sugar concentration.

\section{Discussion}

\section{Domestication Syndrome for Tropical FRUITS}

We found many traits that differ significantly between wild and cultivated fruits of $C$. cainito. Fruits from cultivated genotypes were larger and had more pulp and less exocarp, resulting in a higher "economic ratio" sensu Clement (1989). Fruit pulp had significantly higher concentrations of sugar, was less acidic, and had lower concentrations of phenolics. Seeds were bigger and more numerous and were less defended with phenolics in cultivated than in wild fruits. These patterns are consistent with the hypothesis of human selection on fruit and seed traits. Historical accounts mention caimito already being cultivated in Panama in the mid-1500 s (cited in Patińo 2002). Although these data are scant, we can infer that caimito has been utilized as a fruit crop for at least 450 years and possibly much longer. Caimito trees may come into bearing within about 15 years, allowing us to estimate that a minimum of 30 generations or possible rounds of human-mediated selection have occurred to date. Interestingly, early historical accounts mention the presence of large and smallfruited types (Grisebach 1864; Sloane 1725), suggesting that substantial selection may have already occurred by that time.

The sugar concentration in $C$. cainito is extremely high. In 2008 we measured a mean ${ }^{\circ}$ Brix of 14.9, with a maximum value of 28 . These values are higher than for the majority of domesticated fruits commonly reported, closest to very sweet fruits like pineapple and papaya (http://www.highbrixgardens. com/pdf/Refractive_Index_of_Crop_Juices.pdf),

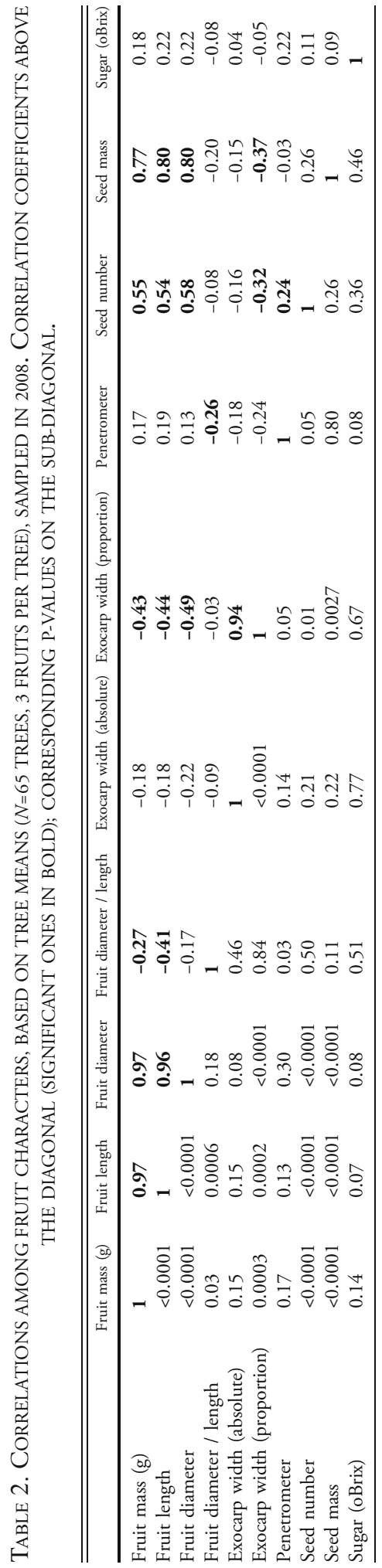




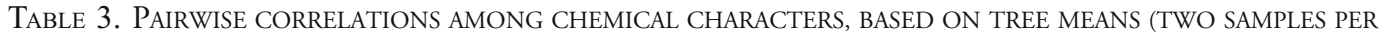
TREE) SAMPLED IN 2006. CORRELATION COEFFICIENTS; CORRESPONDING P-VALUES (WITH SAMPLE SIZE) ON THE SUB-DIAGONAL.

\begin{tabular}{lcccc}
\hline \hline & Phenolics in pulp (mg/100 g GAE) & Phenolics in seeds (mg/100 g GAE) & $\mathrm{pH}$ of pulp & Sugars ('Brix) \\
\hline Phenolics in pulp (mg/100 g GAE) & 1 & -0.16 & -0.29 & -0.11 \\
Phenolics in seeds (mg/100 g GAE) & $0.65(11)$ & 1 & -0.01 & -0.34 \\
pH of pulp & $0.25(18)$ & $0.97(17)$ & 1 & -0.09 \\
Sugars ( ${ }^{\circ}$ Brix) & $0.68(17)$ & $0.30(11)$ & $0.74(17)$ & 1 \\
\hline
\end{tabular}

access date 19 April 2010. The mean value for ${ }^{\circ}$ Brix increased $22 \%$ from wild to cultivated fruits, from 13.6 to 16.6. It is interesting to note that even the wild fruits are very sweet, which may have predisposed this species to early selection as a cultivar.

The reduction we saw in levels of phenolics in the pulp is consistent with a human preference for fruits with less bitterness (Baker 1972; Johns 1990). However, while a reduction in phenolics may indicate direct selection for palatability, it may also reflect an indirect effect of selection on the production of larger, sweeter fruits. Rosenthal and Dirzo (1997) suggest that selection for yield may result indirectly in the reallocation of energy away from defense, because of physiological constraints and tradeoffs.

While all these differences were significant, the Discriminant Analysis showed that the great majority of the variance distinguishing wild from

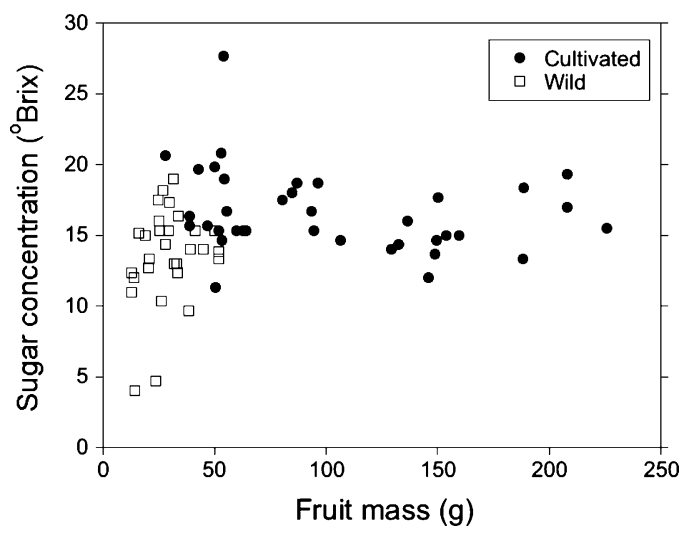

Fig. 4. Sugar concentration ( ${ }^{\circ}$ Brix) by fresh fruit mass (g) for means (over three fruits each) of individual Chrysophyllum cainito trees in central Panama. Filled circles are cultivated trees, open squares are wild trees. A Discriminant Function selected these two variables as most important in distinguishing cultivated from wild trees. cultivated classes was driven by fruit size, with sugar concentration also contributing. This suggests that humans may have selected primarily for increased fruit size in this species, a hypothesis that could be tested with ethnobotanical studies.

\section{Environmental vs. Genetic Contributions}

Many of the traits we measured, such as fruit size or sugar content, could be influenced by environmental conditions. Cultivated trees are likely to experience less competition for light, water, and nutrients than do wild trees. However, several lines of evidence suggest that there is a large genetic component to the traits that distinguish wild from cultivated trees. First, both classes of trees, but especially the wild individuals, came from a wide range of environmental conditions. Some of the wild trees are now in open areas because the forest was cut around them, or are on the edges of forest fragments and therefore have access to more light and possibly nutrients than wild trees in the center of the forest. When we categorize the wild trees for their location, we see no trend toward differences in ${ }^{\circ}$ Brix between trees on edges or in the open vs. trees in closed-canopy forests (data not shown). We do see evidence suggesting that edge fruits are

Table 4. Correlations BetweEn trait VAlues in 2007 AND 2008, FOR THE SUBSET OF TREES $(N=28)$ FOR WHICH FRUITS WERE COLLECTED IN BOTH YEARS.

\begin{tabular}{lcc}
\hline \hline Trait & $r$ & $P$ \\
\hline Fruit mass & 0.8853 & $<0.0001$ \\
Fruit length & 0.8701 & $<0.0001$ \\
Fruit diameter & 0.8995 & $<0.0001$ \\
Diameter/Length & 0.7682 & $<0.0001$ \\
Penetrometer & 0.5104 & 0.0055 \\
Proportion Exocarp & 0.4191 & 0.0211 \\
Sugar concentration $\left({ }^{\circ}\right.$ Brix) & 0.3980 & 0.0398 \\
Seed number & 0.6652 & 0.0001 \\
Seed mass & 0.5305 & 0.0037 \\
\hline
\end{tabular}


slightly bigger, a difference of about $10 \mathrm{~g}$; this is substantially lower than the $73 \mathrm{~g}$ difference between the wild and cultivated means. Second, despite year-to-year variation in environmental conditions such as timing and intensity of the dry season, we saw very high correlations between years (and also among fruits on a tree) in trait values, especially for traits related to fruit size. We have recently planted a broad sample of wild and cultivated genotypes in two field plantations in Panama, which in 10 to 20 years should provide a better estimate of the genetic contribution to variation in this species.

\section{Effect of Cultivation on the Variance OF TRAITS}

For most traits, we found no difference in trait variance between wild and cultivated samples. However, we did find significantly greater variance among cultivated trees than among wild trees for fruit mass and seed number (although the difference for seed number disappeared when log-transformed data were used). In contrast, there was lower variance among cultivated trees for the concentration of phenolics in pulp. Through the process of domestication, we expect to see genetic variation strongly reduced for "domestication genes," those traits that are critical for bringing the species into cultivation, while genetic variation should increase for "crop diversification genes," reflecting a range of preferences during selection (e.g., Doebley et al. 2006; Fuller 2007; Harlan et al. 1973; Hillman and Davies 1990; Purugganan and Fuller 2009). Domesticated plants often show more intraspecific variation than their wild relatives for traits of interest to people (e.g., Bellon and Brush 1994; Morimoto et al. 2005), even in cases where there is an overall reduction in genetic diversity due to a domestication bottleneck (Tanksley 2004). The reduced variance we found for phenolics may indicate consistent selection against bitterness, while the increased variance for fruit size could possibly reflect a range of preferences by the distinct cultural groups that utilize this species in central Panama, including Emberá and Wounaan communities, as well as people of Hispanic and Antillean descent. As mentioned earlier, caimito in this region may also include some genotypes transported from the Antilles. Ethnobotanical studies aimed at understanding cultural preferences, selection targets, and selection intensity could help elucidate this issue.
However, it seems more likely that the broad range in fruit size is generated by a lack of fixation of alleles associated with domestication due to a contemporary or historical influx of wild-type genes, as well as recombination among cultivated genotypes. Zohary and Spiegel-Roy (1975) have suggested that most fully domesticated tree crops are asexually propagated, at least in the Old World. This is thought to increase uniformity and reduce the production of unwanted intermediate forms, particularly as many tree crops are highly heterozygous and show an outcrossing sexual system. Chrysophyllum cainito is not propagated asexually in Panama. The mating system of C. cainito has not been studied, but the species has small flowers that are pollinated by small bees (e.g., Tetragonisca spp., I. Parker and I. López, personal observation), and we expect that it is primarily outcrossing like similar tropical lowland tree species (reviewed in Ward et al. 2005). We suggest that the extremely wide range of variation in fruit size among cultivated phenotypes is what might be predicted for a fruit tree species in the early stages of domestication. This is consistent with the findings of Leakey et al. (2004) for the semidomesticated fruit trees Dacryodes edulis and Irvingia gabonensis. However, unlike those species, the distributions of traits in our cultivated samples of C. cainito did not show statistically significantly more skew than wild populations (data not shown).

\section{Correlations among Traits}

We found a strong positive correlation between fruit size and both seed number and seed size. A positive correlation between fruit size and seed number has also been reported in sweet pepper (Capsicum annuum, Marcelis and HofmanEijer 1997) and tomato (Solanum lycopersicum, Lippman and Tanksley 2001; Marcelis and HofmanEijer 1997; van der Knaap and Tanksley 2003), and for these species the genetic basis is known. The correlations that we observe in C. cainito may be due to pleiotropic effects, tight linkage of loci, or a combination of these factors. From a physiological perspective, fruit size may be directly related to seed number because the developing seeds are a source of auxin for the developing fruit; therefore, an increase in number of seeds results in a larger fruit (Nitsch 1950). In addition, a general "gigas effect" in domesticates can produce an increase in organ size through increased cell number and/or cell size 
(reviewed in Pickersgill 2007), which could also explain the positive correlation of fruit size and seed size/number observed in caimito. Therefore, even if human preferences were in the direction of smaller seeds, as is the case in tempesquistle (Sideroxylon palmeri, Sapotaceae, Gonzalez-Soberanis and Casas 2004), or fewer seeds, genetic and physiological factors may constrain seed size and number in cultivated C. cainito.

\section{Conclusions}

In summary, our results demonstrate clear and significant phenotypic differences between fruits of cultivated and wild $C$. cainito trees in Panama, and we attribute these differences to the effects of human selection associated with the process of domestication. Caimito thus appears to fit Clement's (1999) definition of a "semi-domesticated" species. Interestingly, although cultivated and wild $C$. cainito trees in Panama form two phenotypically distinct classes, we have found that they are not clearly differentiated at microsatellite loci, and that both classes show high levels of genetic diversity (Petersen et al. 2008). This implies that the emergence of domestication traits in fruits and seeds is likely to have resulted from human selection acting on multiple wild genotypes.

The mosaic of protected forests and rural communities across central Panama has led to the close physical proximity of cultivated trees and wild populations (Fig. 1). In light of probable gene flow between these groups, it is perhaps surprising that we found such striking differences between them. Gene flow from wild trees to cultivated ones could reduce the signal of domestication. At the same time, gene flow from selected trees back into forests could have negative fitness effects for wild populations. Our results point to the possibility of complex evolutionary dynamics of both cultivated and ancestral forms in this semi-domesticated taxon.

\section{Acknowledgements}

We thank Humberto Membache, Amaranto Membache, and Harold Henry for field assistance, and Carl Jones for help in adapting the fruit chemistry protocols. Barry Nickel designed and created the map. Sara Grove, Sarah Swope, John Banks, Justin Cummings, Krikor Andonian, and Carla Fresquez provided comments on the manuscript, and Jorge Zegbe helped edit the Spanish abstract. Financial support for this project was provided by the UCSC Committee on Research, the Jane Carver Foundation, the Jean H. Langenheim Endowed Chair in Plant Ecology and Evolution, and a Fulbright Fellowship to IMP.

\section{Open Access}

This article is distributed under the terms of the Creative Commons Attribution Noncommercial License which permits any noncommercial use, distribution, and reproduction in any medium, provided the original author(s) and source are credited.

\section{Literature Cited}

Azuma, K., M. Nakayama, M. Koshioka, K. Ippoushi, Y. Yamaguchi, K. Kohata, Y. Yamauchi, H. Ito, and H. Higashio. 1999. Phenolic Antioxidants from the Leaves of Corchorus olitorius L. Journal of Agricultural and Food Chemistry 47:3963-3966.

Baker, H. G. 1972. Human Influences on Plant Evolution. Economic Botany 26:32-43.

Bellon, M. R. and S. B. Brush. 1994. Keepers of Maize in Chiapas, Mexico. Economic Botany 48:196-209.

Blancas, J., A. Casas, R. Lira, and J. Caballero. 2009. Traditional Management and Morphological Patterns of Myrtillocactus schenckii (Cactaceae) in the Tehuacán Valley, Central Mexico. Economic Botany 63:375-387.

Bost, J. B. 2009. Edible Plants of the Chinantla, Oaxaca, Mexico with an Emphasis on the Participatory Domestication Prospects of Persea schiedeana. M.S. thesis, University of Florida, Gainesville.

Browne, P. 1756. In the Civil and Natural History of Jamaica. London, U.K., page 171.

Clement, C. R. 1989. A Center of Crop Genetic Diversity in Western Amazonia. Bioscience 39:624-631.

1999. 1492 and the Loss of Amazonian Crop Genetic Resources. I. The Relation between Domestication and Human Population Decline. Economic Botany 53:188-202.

Condit, R., N. Pitman, E. G. Leigh, J. Chave, J. Terborgh, R. B. Foster, P. Nunez, S. Aguilar, R. Valencia, G. Villa, H. C. Muller-Landau, E. Losos, and S. P. Hubbell. 2002. Beta-Diversity in Tropical Forest Trees. Science 295:666-669.

De Candolle, A. 1885. Origin of Cultivated Plants. [S.N.], Appleton, New York. 
Doebley, J. F., B. S. Gaut, and B. D. Smith. 2006. The Molecular Genetics of Crop Domestication. Cell 127:1309-1321.

Fuller, D. Q. 2007. Contrasting Patterns in Crop Domestication and Domestication Rates: Recent Archaeobotanical Insights from the Old World. Annals of Botany 100:903-924.

Gepts, P. 2004. Crop Domestication as a LongTerm Selection Experiment. Plant Breeding Reviews 24:1-44.

Gonzalez-Soberanis, C. and A. Casas. 2004. Traditional Management and Domestication of Tempesquistle, Sideroxylon palmeri (Sapotaceae) in the Tehuacan-Cuicatlan Valley, Central Mexico. Journal of Arid Environments 59:245-258.

Grisebach, A. 1864. Flora of the British West Indian Islands. Lovell Reeve, London.

Haq, N., C. Bowe, and Z. E. Dunsiger. 2008. Challenges to Stimulating the Adoption and Impact of Indigenous Fruit Trees in Tropical Agriculture. Pages 50-69 in F. K. Akinnifesi, R. R. B. Leakey, O. C. Ajayi, G. Sileshi, Z. Tchoundjeu, P. Matakala, and F. R. Kwesiga, eds., Indigenous Fruit Trees in the Tropics: Domestication, Utilization and Commercialization. CAB International, Wallingford.

Harlan, J. R., J. Wet, and E. G. Price. 1973. Comparative Evolution of Cereals. Evolution 27:311-325.

Hillman, G. C. and M. S. Davies. 1990. Domestication Rates in Wild-Type Wheats and Barley under Primitive Cultivation. Biological Journal of the Linnean Society 39:39-78.

Hughes, C. E., R. Govindarajulu, A. Robertson, D. L. Filer, S. A. Harris, and C. D. Bailey. 2007. Serendipitous Backyard Hybridization and the Origin of Crops. Proceedings of the National Academy of Sciences of the United States of America 104:14389-14394.

Jackson, F. L. C. 1991. Secondary Compounds in Plants (Allelochemicals) as Promoters of Human Biological Variability. Annual Review of Anthropology 20:505-546.

Johns, T. 1990. With Bitter Herbs They Shall Eat It: Chemical Ecology and the Origins of Human Diet and Medicine. University of Arizona Press, Tucson.

Leakey, R., S. Shackleton, and P. Plessis. 2005a. Domestication Potential of Marula (Sclerocarya birrea Subsp caffra) in South Africa and Namibia: 1. Phenotypic Variation in Fruit Traits. Agroforestry Systems 64:25-35.
K. Pate, and C. Lombard. 2005b. Domestication Potential of Marula (Sclerocarya birrea Subsp caffra) in South Africa and Namibia: 2. Phenotypic Variation in Nut and Kernel Traits. Agroforestry Systems 64:37-49.

Leakey, R. R. B., Z. Tchoundjeu, R. I. Smith, R. C. Munro, J. M. Fondoun, J. Kengue, P. O. Anegbeh, A. R. Atangana, A. N. Waruhiu, E. Asaah, C. Usoro, and V. Ukafor. 2004. Evidence That Subsistence Farmers Have Domesticated Indigenous Fruits (Dacryodes edulis and Irvingia gabonensis) in Cameroon and Nigeria. Agroforestry Systems 60:101-111.

Levene, H. 1960. Robust Tests for Equality of Variances. Pages 278-292 in I. Olkin, S. G. Ghurye, W. Hoeffding, W. G. Madow, and H. B. Mann, eds., Contributions to Probability and Statistics: Essays in Honor of Harold Hotelling. Stanford University Press, Stanford.

Lippman, Z. and S. D. Tanksley. 2001. Dissecting the Genetic Pathway to Extreme Fruit Size in Tomato Using a Cross between the SmallFruited Wild Species Lycopersicon pimpinellifolium and L-Esculentum Var. Giant Heirloom. Genetics 158:413-422.

Maranz, S. and Z. Wiesman. 2003. Evidence for Indigenous Selection and Distribution of the Shea Tree, Vitellaria paradoxa, and Its Potential Significance to Prevailing Parkland Savanna Tree Patterns in Sub-Saharan Africa North of the Equator. Journal of Biogeography 30:1505-1516.

Marcelis, L. F. M. and L. R. B. HofmanEijer. 1997. Effects of Seed Number on Competition and Dominance among Fruits in Capsicum annuum L. Annals of Botany 79:687-693.

Miller, A. and B. Schaal. 2005. Domestication of a Mesoamerican Cultivated Fruit Tree, Spondias purpurea. Proceedings of the National Academy of Sciences of the United States of America 102:12801-12806.

Morimoto, Y., P. Maundu, H. Fujimaki, and H. Morishima. 2005. Diversity of Landraces of the White-Flowered Gourd (Lagenaria siceraria) and Its Wild Relatives in Kenya: Fruit and Seed Morphology. Genetic Resources and Crop Evolution 52:737-747.

Morton, J. F. 1987. Fruits of Warm Climates. Julia F. Morton, Miami.

Nitsch, J. P. 1950. Growth and Morphogenesis of the Strawberry as Related to Auxin. American Journal of Botany 37:211-215. 
Panama Canal Authority: Republic of Panama. 2008. Physical Monitoring Downloads [Online]. Available by The Meteorology and Hydrology Branch, Smithsonian Tropical Research Institute. http://striweb.si.edu/esp/ physical_monitoring/download_acp.htm (15 April 2008).

Patiño, V. M. 2002. Historia Y Dispersion De Los Frutales Natives Del Neotrópico. Centro Internacional de Agricultura Tropical, Cali.

Pennington, T. D. 1990. Sapotaceae. New York Botanical Garden, Bronx.

Perez and Condit, Tree Atlas of Panama. https:// ctfs.arnarb.harvard.edu/webatlas/maintreeatlas. php (29 April 2010).

Petersen, J., I. Parker, and D. Potter. 2008. Out of Panama? Microsatellite Variation Suggests a Southern Central American Origin of the Star Apple, Chrysophyllum cainito L. Page 26 in P. Gepts and T. Famula, eds., Harlan II: Biodiversity in Agriculture: Domestication, Evolution, and Sustainability. University of California, Davis.

Pickersgill, B. 2007. Domestication of Plants in the Americas: Insights from Mendelian and Molecular Genetics. Annals of Botany 100:925-940.

Purugganan, M. D. and D. Q. Fuller. 2009. The Nature of Selection During Plant Domestication. Nature 457:843-848.

Pyke, C. R., R. Condit, S. Aguilar, and S. Lao. 2001. Floristic Composition across a Climatic Gradient in a Neotropical Lowland Forest. Journal of Vegetation Science 12:553-566.

Rindos, D. 1984. The Origins of Agriculture: An Evolutionary Perspective. Academic, Orlando.

Rosenthal, J. and R. Dirzo. 1997. Effects of Life History, Domestication and Agronomic Selection on Plant Defence against Insects: Evidence from Maizes and Wild Relatives. Evolutionary Ecology 11:337-355.

Schreckenberg, K., A. Awono, A. Degrande, and C. Mbosso. 2006. Domesticating Indigenous Fruit Trees as a Contribution to Poverty Reduction. Forests, Trees, and Livelihoods $16: 35-51$.
Seemann, B. 1852. The Botany of the Voyage of H.M.S. Herald: Under the Command of Captain Henry Kellett, R.N., C.B., During the Years 1845-51. Lovell Reeve, London.

Simpson, B. B. and M. C. Ogorzaly. 2001. Economic Botany, Plants in Our World, 3rd edition. McGraw Hill, New York.

Singleton, V. and J. Rossi. 1965. Colorimetry of Total Phenolics with Phosphomolybdic-Phosphotungstic Acid Reagents. American Journal of Enology and Viticulture 16:144-158.

Sloane, H. 1725. A Voyage to the Islands Madera, Barbados, Nieves, S. Christophers and Jamaica: With the Natural History of the Herbs and Trees, Four-Footed Beasts, Fishes, Birds, Insects, Reptiles, \&C. Printed by B. M. for the author, London.

Standley, P. C. and L. O. Williams. 1967. Flora of Guatemala. Fieldiana 24:211-244.

Tanksley, S. D. 2004. The Genetic, Developmental, and Molecular Bases of Fruit Size and Shape Variation in Tomato. Plant Cell 16: S181-S189.

van der Knaap, E. and S. D. Tanksley. 2003. The Making of a Bell Pepper-Shaped Tomato Fruit: Identification of Loci Controlling Fruit Morphology in Yellow Stuffer Tomato. TAG Theoretical and Applied Genetics 107:139-147.

Ward, M., C. Dick, R. Gribel, and A. Lowe. 2005. To Self or Not to Self? A Review of Outcrossing and Pollen Mediated Gene Flow in Neotropical Trees. Heredity 95:246-254.

Wiersum, K. F. 1997. From Natural Forest to Tree Crops, Co-Domestication of Forests and Tree Species, an Overview. Netherlands Journal of Agricultural Sciences 45:425-438.

Wright, S. I., I. V. Bi, S. G. Schroeder, M. Yamasaki, J. F. Doebley, M. D. McMullen, and B. S. Gaut. 2005. The Effects of Artificial Selection of the Maize Genome. Science 308:1310-1314.

Zohary, D. 2004. Unconscious Selection and the Evolution of Domesticated Plants. Economic Botany 58:5-10.

and P. Spiegel-Roy. 1975. Beginnings of Fruit Growing in the Old World. Science 187:319-327. 